\title{
Use of rDNA polymorphism for identification of Heterophyidae infecting freshwater fishes
}

\author{
R. Dzikowski ${ }^{1, *}$, M. G. Levy ${ }^{2}$, M. F. Poore ${ }^{2}$, J. R. Flowers ${ }^{2}$, I. Paperna ${ }^{1}$ \\ ${ }^{1}$ Department of Animal Sciences, Faculty of Agriculture, Food and Environmental Sciences, Hebrew University of \\ Jerusalem, PO Box 12, Rehovot 76100, Israel \\ ${ }^{2}$ Department of Population Health and Pathobiology, College of Veterinary Medicine, North Carolina State University, \\ 4700 Hillsborough St., Raleigh 27606, North Carolina, USA
}

\begin{abstract}
Infections by trematodes are among the most common fish-borne zoonoses. Metacercariae of the Family Heterophyidae in marine and freshwater fishes are nonfastidious in their choice of definitive hosts, and therefore, cause infections in human and domestic animals. In the present study, species-specific polymerase chain reaction (PCR) assays were developed for identifying and differentiating the various species examined. Sequencing and aligning the 18S (SSU) rDNA revealed interspecific variation for which species-specific DNA oligonucleotides were designed and used for the identification of 6 heterophyid species recovered from piscivorous birds. The oligonucleotides were further used to evaluate the various stages (cercariae recovered from snails, metacercariae recovered from fish and adult trematodes) of the digeneans. By applying this method we elucidated for the first time the life cycle of Pygidiopsis genata. The phylogenetic interrelationship among the newly sequenced species of Heterophyidae is outlined.
\end{abstract}

KEY WORDS: Digenea $\cdot$ Heterophyidae $\cdot$ Birds $\cdot$ Fish $\cdot 18$ S rDNA gene $\cdot$ SSU

Resale or republication not permitted without written consent of the publisher

\section{INTRODUCTION}

Trematodes of the Family Heterophyidae Odhner, 1914 are significant both as fish pathogens and as agents causing zoonotic infections among humans consuming raw or incompletely cooked fish. Severe infection by the heterophyid Centrocestus spp. in the gills (Paperna 1996), Haplorchis pumilio in the connective tissue (Sommerville 1982) and more recently heart infections by Phagicola longa (R. Dzikowski \& I. Paperna unpubl. data) have resulted in massive losses in farmed cichlid fish (Paperna 1995). Because the adult stages of many heterophyids are nonfastidious in their choice of definite hosts, infections with severe clinical consequences have been reported in humans after consuming fish infected with metacercariae (Deardorff \& Overstreet 1990, Ko 1995).

Witenberg (1929) described 14 species of the Family Heterophyidae from both naturally and experimentally infected avian and mammalian definitive hosts. While specific determination of larval stages by morpho- logical traits is often difficult and ambiguous, experimental demonstration of the life history is frequently unachievable due to the unidentified nature of the specific intermediate or definitive host. The use of molecular methodologies has allowed links to be elucidated between the various developmental stages, i.e. cercariae, metacercariae and adults of specific trematodes (Cribb et al. 1998, Jousson et al. 1998, Anderson 1999, Bartoli et al. 2000, Levy et al. 2002). Various ribosomal genes, especially the $18 \mathrm{~S}$ (small subunit, SSU) along with the inter-specific polymorphic regions, include highly conserved regions for which 'universal primers' can be designed for amplification of this gene from a newly studied species (Hillis \& Dixon 1991, Littlewood \& Olson 2001). PCR methodologies have also enabled amplification of these genes from a single cercaria without DNA extraction (Grevelding et al. 1997).

The objectives of the present study were to develop species-specific oligonucleotides as a diagnostic tool for the identification of heterophyid species recovered from piscivorous birds in Israel. These oligonucleotides 
were then used for identification of cercariae recovered from snails and metacercariae recovered from fish, demonstrating their usefulness as a diagnostic tool important for fish and public health. An effort made to define the entire life history of Pygidiopsis genata was successfully carried out. Finally we attempted to examine the phylogenetic links between the Heterophyidae and various other trematodes that were concurrently investigated.

\section{MATERIALS AND METHODS}

Sources of parasites and morphological characterization. During 2000 to 2002, adult trematodes were collected from 45 cormorants Phalacrocorax carbo, 4 little egrets Egretta garzetta, 3 night herons Nycticorax nycticorax, 2 white pelicans Pelecanus onocrotalus and a catfish Clarias gariepinus. Collection permits were obtained from the Office of Nature Conservation, Ministry of Environmental Quality, Israel.

Trematodes were collected from the sedimentation of the intestine content, then removed and placed in clean physiological saline and preserved in $70 \%$ ethanol. Several specimens of each species were fixed in $70 \%$ ethanol overnight under light pressure, stained with Aceto-Carmine, and whole mounted for morphologic examination.

Metacercariae of Centrocestus sp. (gills), Haplorchis sp. (subcutaneous) Phagicola sp. (heart: conus arteriosus) and Pygidiopsis sp. (kidney), and an unidentified metacercaria from the liver, were obtained from Tilapia zillii (Cichlidae). The fish were collected from commercial fish ponds and Lake Kinneret. Clinostomum complanatum metacercariae (subcutaneous, intermuscular) were collected from Barbus canis (Cyprinidae) from Lake Kinneret. All metacercariae were preserved in $70 \%$ ethanol.

Cercariae were collected from 3 species of freshwater snails (Melanoides tuberculata, Melanopsis costata and Bythinia hawaderiana) from Lake Kinneret. Data (snail host, preliminary identifications, etc.) for the cercariae were recorded and individual specimens were frozen at $-70^{\circ} \mathrm{C}$ or fixed in $70 \%$ ethanol.

Gene amplification. Individual worms, metacercariae, and cercariae were washed overnight in buffer (10 mM Tris-EDTA). Following another 2 washes $(1 \mathrm{~h}$ each), a single metacercariae or cercariae was placed into a $0.2 \mathrm{ml}$ PCR tube and gently crushed prior to DNA extractions or direct amplification. DNA was extracted from single adult worms using a DNeasy tissue kit (Qiagen) according to the manufacturer's instructions. Polymerase chain reactions were carried out in $50 \mu \mathrm{l}$ volumes using $10 \times$ buffer, $2.5 \mathrm{U}$ Taq polymerase (HotStarTaq, Qiagen), $10 \mathrm{mM}$ of each deoxynucleotide triphosphate and $100 \mathrm{ng}$ of each primer. Amplification of the 18S (SSU) and internal transcribed spacer (ITS) of the rDNA gene were carried out as described in Levy et al. (2002) using universal trematodes primer sets. These primer sets could not amplify the rDNA of the majority of Heterophyidae spp. found in the present study. Therefore, different primers designated for conserved regions were used to amplify the $18 \mathrm{~S}$ regions of Phagicola longa, Haplorchis pumilio, H. taichui, Centrocestus sp., the unidentified liver metacercaria (Het 18S F/R) and Pygidiopsis genata (Uni 18S F/R) (Table 1). Different primers were also used to amplify the ITS regions of H. pumilio, H. taichui, Centrocestus sp., P. genata (19 F/A2 R) and P. longa (412 F/204a R) (Table 1). PCR amplicons were subjected to electrophoresis in $1.5 \%$ agarose gels stained with ethidium bromide and visualized under ultraviolet light.

PCR products of all species, except the 18S of Haplorchis pumilio, H. taichui, Centrocestus sp. and Pygidiopsis genata were purified using a Qiagene QIAquick PCR purification kit and sequenced directly on an ABI377 DNA sequencer using the Deoxy ${ }^{\mathrm{TM}}$ Terminator Cycle sequencing kit (Applied Biosystems $\mathrm{AB}^{\mathrm{TM}}$ ) following the manufacturer's instructions.

PCR products of the 18S amplifications of Haplorchis pumilio, H. taichui, Centrocestus sp. and Pygidiopsis genata contained extraneous amplicons. The amplicons of interest were cut out of the gels and further purified using a Qiagene gel Extraction Kit and cloned into a pGEM-T Easy Vector system, utilizing blue/ white selection (Sambrook et al. 1989). Plasmids from white colonies were screened for inserts using PCR amplification. Positive colonies were incubated overnight and then purified using the High Pure Purification Kit (Roche), quantified by spectrophotometry and sequenced.

Sequencing of the $18 \mathrm{~S}$ regions was done using the internal primers $18 \mathrm{~S} 360 \mathrm{~F}$ and 18S 1533R (Levy et al. 2002). The sequencing of the ITS of Haplorchis pumilio Pygidiopsis genata and Centrocestus sp. was done using the internal primer ITS $455 \mathrm{~F}$ (Table 1). Sequencing the $3^{\prime}$ of the $18 \mathrm{~S}$ of Centrocestus sp., P. genata, $H$. taichui and $H$. pumilio required another PCR amplification using the reverse primers Cnt ITS 154 R, Pyg ITS $140 \mathrm{R}$, tai ITS $140 \mathrm{R}$ and pum ITS $140 \mathrm{R}$, respectively, with Het $1824 \mathrm{~F}$ (annealing temperature $58^{\circ} \mathrm{C}$ and $30 \mathrm{~s}$ at $72^{\circ} \mathrm{C}$ ). Sequence analyses were done following the same procedures described previously in Levy et al. (2002). Species-specific oligonucleotide primer sets were designed for the 6 heterophyid species: Centrocestus sp., H. pumilio, H. taichui, Dexiogonimus ciureanus, Phagicola longa and P. genata using the specific forward primers Cnt $1463 \mathrm{~F}$, pum $1463 \mathrm{~F}$, tai 1463 F, Dex 1463 F, Pha 1463 F and Pyg 1463 F, 
Table 1. Oligonucleotide primers used to sequence and assay rDNA $18 \mathrm{~S}$ and ITS by polymerase chain reaction (PCR)

\begin{tabular}{|c|c|c|c|c|}
\hline Primer type & Designation & Species & Sequence $5^{\prime}-3^{\prime}$ & $\begin{array}{l}\text { Annealing } \\
\text { temperature } \\
\left({ }^{\circ} \mathrm{C}\right)\end{array}$ \\
\hline Heterophyidae $18 \mathrm{~S}$ & 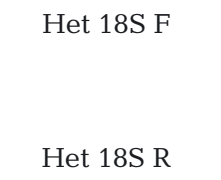 & $\begin{array}{l}\text { Liver metacercaria } \\
\text { Haplorchis pumillo } \\
\text { H. taichui } \\
\text { Centrocestus sp. } \\
\text { Pagicola longa }\end{array}$ & ACG GAA ACC TTG TTA CGA & 53 \\
\hline Trematode universal 18S & $\begin{array}{l}\text { Uni } 18 \text { S F } \\
\text { Uni } 18 \text { S R }\end{array}$ & Pygidiopsis genata & $\begin{array}{l}\text { GCT TGT CTC AGA GAT TAA GCC } \\
\text { ACG GAA ACC TTG TTA CGA C }\end{array}$ & 50 \\
\hline Heterophyidae ITS & $\begin{array}{l}19 \mathrm{~F} \\
\\
\mathrm{~A} 2 \mathrm{R} \\
412 \mathrm{~F} \\
204 \mathrm{Ra}\end{array}$ & $\begin{array}{l}\text { H. pumilio } \\
\text { H. taichui } \\
\text { Centrocestus sp. } \\
\text { P. genata } \\
\text { P. longa }\end{array}$ & $\begin{array}{c}\text { TAT GCT TAA GTT CAG CGG GT } \\
\text { TAA CAG GTC TGT GAT } \\
\text { ATA TGC TTA AAT TCA GCG GGT }\end{array}$ & 53 \\
\hline ITS sequencing (internal) & $\begin{array}{l}\text { ITS } 455 \mathrm{~F} \\
\qquad \text { Uni }\end{array}$ & $\begin{array}{l}\text { H. pumilio } \\
\text { P. genata } \\
\text { Centrocestus sp. } \\
\text { entified Plagiorchiid }\end{array}$ & $\begin{array}{l}\text { CTC TTC ATC GAC ACA CGA GC } \\
\text { sp. }\end{array}$ & 50 \\
\hline $\begin{array}{l}\text { Heterophydiae 18S 3' } \\
\text { sequencing }\end{array}$ & $\begin{array}{l}\text { Cnt ITS } 154 \mathrm{R} \\
\text { Pyg ITS } 140 \mathrm{R} \\
\text { tai ITS } 140 \mathrm{R} \\
\text { pum ITS } 140 \mathrm{R} \\
\text { Het } 1824 \mathrm{~F}\end{array}$ & $\begin{array}{l}\text { Centrocestus sp. } \\
\text { P. genata } \\
\text { H. taichui } \\
\text { H. pumilio } \\
\text { All } 4 \text { above }\end{array}$ & $\begin{array}{l}\text { CAC CGT AGG CAG ACA AGG CT } \\
\text { TCC GAT ATC GAC AGC AAA CG } \\
\text { ACG GAA CTG GCG TCG ATC CG } \\
\text { GTG ATC CCG GAG TTC ACT AT } \\
\text { ACC GCC CGT CGC TAC TAC CG }\end{array}$ & 58 \\
\hline Species specific primers & $\begin{array}{l}\text { Cnt } 1463 \mathrm{~F} \\
\text { pum } 1463 \mathrm{~F} \\
\text { tai } 1463 \mathrm{~F} \\
\text { Dex } 1463 \mathrm{~F} \\
\text { Pha } 1463 \mathrm{~F} \\
\text { Pyg } 1463 \mathrm{~F} \\
\text { Het } 1824 \mathrm{R}\end{array}$ & $\begin{array}{l}\text { Centrocestus sp. } \\
\text { H. pumilio } \\
\text { H. taichui } \\
\text { D. ciureanus } \\
\text { P. longa } \\
\text { P. genata } \\
\text { All } 6 \text { above }\end{array}$ & $\begin{array}{l}\text { ACC CGT GCG GGT GGC GGT GAT CA } \\
\text { ACT CGT GCA GGT AGC GGT GGT CG } \\
\text { GCC TGT GCA GGT AGC GGT GCT CG } \\
\text { GCT CGT GCA GGT GGC GGT GCT CG } \\
\text { ACT CGT GCG GGT GGC GGT ATT CT } \\
\text { ATC CGT GCA GGT GGC GGT TAT CT } \\
\text { AAT CGG TAG TAG CGA CGG GCG GT }\end{array}$ & $\begin{array}{l}72 \\
72 \\
72 \\
72 \\
69 \\
69 \\
69-72\end{array}$ \\
\hline
\end{tabular}

respectively, with Het $1824 \mathrm{R}$. The cycling conditions were as described in Levy et al. (2002) with few exceptions; the optimal conditions required 34 cycles with annealing temperature set at 69 to $72^{\circ} \mathrm{C}$ (see Table 1) for 45 and $30 \mathrm{~s}$ at $72^{\circ} \mathrm{C}$.

Endonuclease restriction digest. We employed the PCR-RFLP procedure in order to distinguish between Haplorchis pu- milio, H. taichui and Dexiogonimus ciureanus. A $5 \mu \mathrm{l}$ aliquot of the rDNA 18S PCR product $(1.5 \mu \mathrm{g})$ of each species was digested with Hin f1 (Promega) according to the manufacturer's specifications, at $37^{\circ} \mathrm{C}$ for $4 \mathrm{~h}$. Electrophoresis of the resulting fragments was done on a $1.5 \%$ agarose gel and visualized with ethidium bromide.

Phylogeny analysis. The rDNA $18 \mathrm{~S}$ ( 1800 bp) nucleotide sequences were aligned using the aligning tool supplied by the MacOSX ARB phylogenetic program package (34). Phylogenetic trees were generated with the neighbor-joining and maximum likelihood methods with the ARB program package using the Felsenstein correction method, applying a $50 \%$ cutoff filter (34). Branching order was supported by both methods.

\section{RESULTS}

Thirteen trematode species were recovered from birds: Haplorchis pumilio, H. taichui, Centrocestus sp., Pygidiopsis genata, Phagicola longa, Dexiogonimus ciureanus, Clinostomum complanatum, an unidentified species of Strigeidae, Bolbophorus levantinus, Bolbophorus confusus, Paryphostomum radiatum, Petasiger phalacrocoracis and Holostephanus dubinini. An unidentified plagiorchiid and an unidentified metacercaria from the liver were recovered from fish (Table 2).

The rDNA $18 \mathrm{~S}$ and the ITS gene sequences of the 14 adult trematode species as well as that of the unidentified metacercaria (liver), were obtained and submitted to GenBank (Table 2). Based on the alignment of the $18 \mathrm{~S}$ sequences of the subject heterophyid species, there is only 1 polymorphic site between all 6 heterophyid species (starting at $1463 \mathrm{bp}$ of the $5^{\prime}$ end) to which species-specific oligonucleotide primer sets have been designed (Fig. 1).

We used the Centrocestus sp. (from Israel) specific primer (Cnt 1463 F, Het 1824 R) to link the Centro- 


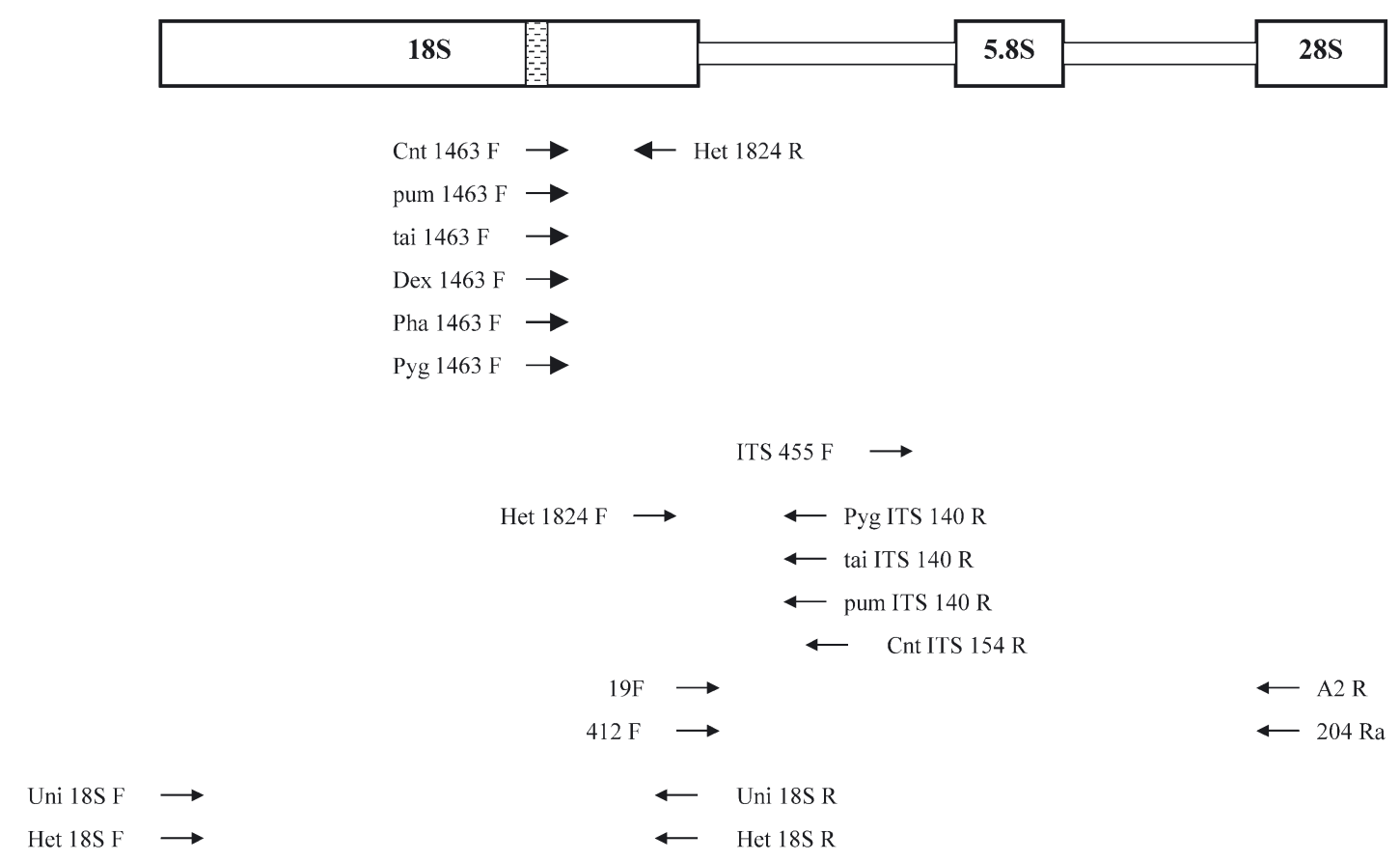

Fig. 1. Map of the PCR primers used for the amplification and sequencing (small arrows) of the 18S and ITS rDNA regions of the digeneans investigated and heterophyids' species-specific primers (big arrows). Arrows indicate priming sense.

国: Heterophyids' polymorphic region

cestus-type pleurolophocercous cercariae, which emerged from the snail Melanoides tuberculata, the Centrocestus sp. metacercaria from the gills of Tilapia zillii and the adult Centrocestus sp. from the cor-

Table 2. Trematode species, recovered from piscivorous birds in Israel during 2000 to 2002, listed with their rDNA 18S-ITS GenBank accession number

\begin{tabular}{|lcc|}
\hline Trematode species & $\begin{array}{c}\text { GenBank } \\
\text { accession number }\end{array}$ & Host \\
\hline Centrocestus sp. (Looss, 1989) & AY245699 & Egretta garzetta \\
Haplorchis pumilio (Looss, 1896) & AY245706 & Phalacrocorax carbo \\
Haplorchis taichui (Nishigori, 1924) & AY245705 & P. carbo \\
Phagicola longa (Ransom, 1920) & AY245703 & P. carbo \\
Pygidiopsis genata Looss, 1907 & AY245710 & P. carbo \\
Dexiogonimus ciureanus Witenberg, 1928 & AY245702 & P. carbo \\
Bolbophorus levantinus (Dubois, 1970) & AF490576 & Nycticorax nycticorax \\
Bolbophorus confusus (Krause, 1914) & AY242851 & Pelecanus onocrotalus \\
Paryphostomum radiatum (Dujardin, 1845) & AY245708 & P. carbo \\
Petasiger phalacrocoracis (Yamaguti, 1939) & AY245709 & P. carbo \\
Holostephanus dubinini Vojtek et Vojtkova, 1968 & AY245707 & P. carbo \\
Clinostomum complanatum (Rudolphi, 1819) & AY245701 & E. garzetta \\
Unidentified Strigeidae sp. Railliet, 1919 & AY245711 & E. garzetta \\
Unidentified Plagiorchiidae sp. & AY245700 & Clarias gariepinus \\
Unidentified metacercaria (Liver) & AY245704 & Tilapia zillii \\
& & \\
\hline
\end{tabular}

morant (Fig. 2A). Using Pygidiopsis genata specific primers (Pyg $1463 \mathrm{~F}$, Het $1824 \mathrm{R}$ ), we have found a specific genetic link between the pleurolophocercous cercariae that emerged from the snail Melanopsis costata, the Pygidiopsis sp. metacercaria found in the kidney of $T$. zillii and the adult $P$. genata found in the cormorant (Fig. 2B). By the same methodology, Phagicola longa specific primers (Pha 1463 F, Het 1824 $\mathrm{R})$ have enabled us to link the Phagicola sp. metacercaria from the heart of $T$. zillii to the adult $P$. longa from the cormorant. The snail host remains unknown, as infected snails were not found (Fig. 2C). Similarly, using the specific primer set (pum 1463 F, Het 1824 R), we have established the genetic association between all the stages of Haplorchis pumilio, including the cercariae in $M$. tuberculata, the metacercariae in $T$. zilli and the adult worms in cormorants (Fig. 2D). 
A. Centrocestus sp.

$\begin{array}{lllllll}1 & 2 & 3 & 4 & 5 & 6 & 7\end{array}$

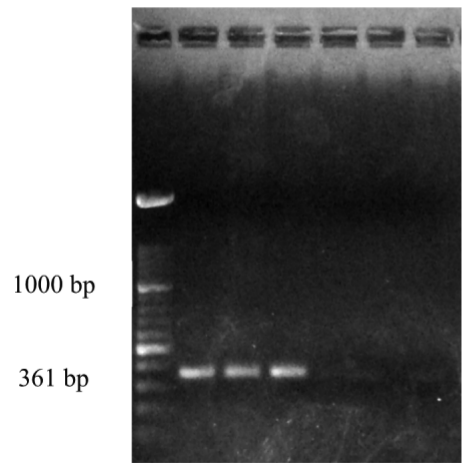

C. Phagicola longa
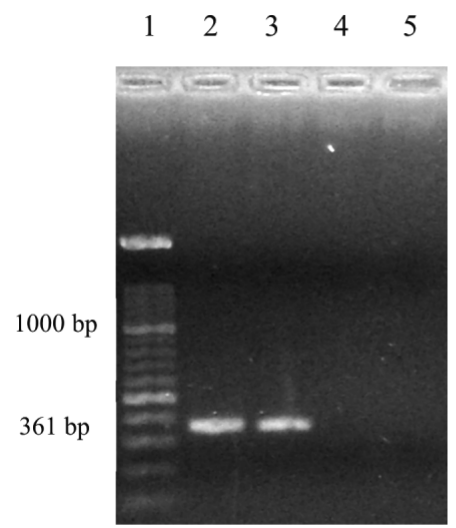

B. Pygidiopsis genata $\begin{array}{lllllll}1 & 2 & 3 & 4 & 5 & 6 & 7\end{array}$

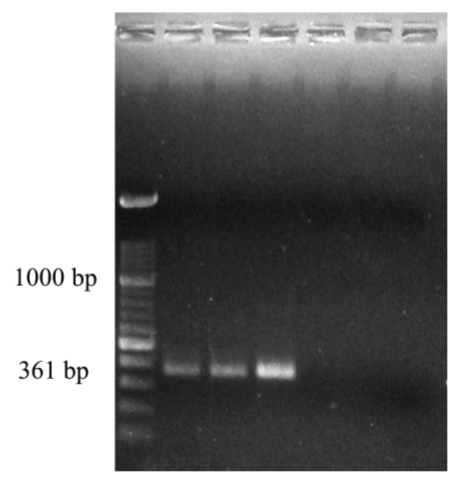

D. Haplorchis pumilio
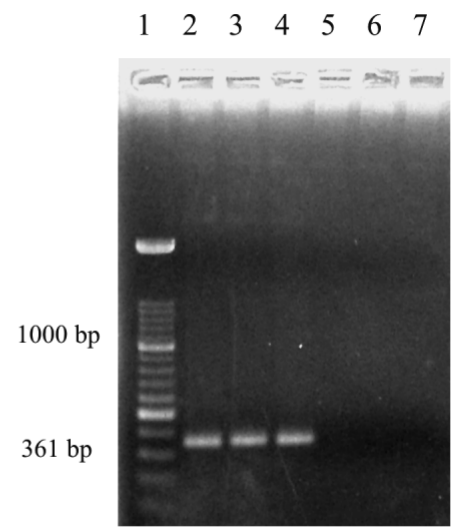

Fig. 2. Agarose gels showing PCR products of heterophyid trematodes using species-specific oligonucleotide primer sets. Lanes are as follows: (A) Centrocestus sp.: 1, 100 bp DNA marker; 2 , single adult; 3 , single metacercaria; 4, single cercaria; 5, Tilapia zillii; 6, Melanoides tuberculata; 7, $\mathrm{H}_{2} \mathrm{O}$. (B) Pygidiopsis genata: 1, 100 bp DNA marker; 2, single adult; 3, single metacercaria; 4, single cercaria; 5, T. zillii; 6, M. costata; 7, $\mathrm{H}_{2} \mathrm{O}$. (C) Phagicola longa: 1, 100 bp DNA marker; 2 , single adult; 3 , single metacercaria; 4 , T. zillii; $5, \mathrm{H}_{2} \mathrm{O}$. (D) Haplorchis pumilio: 1, 100 bp DNA marker; 2, single adult; 3, single metacercaria; 4, single cercaria; 5, T. zillii; 6, M. tuberculata; $7, \mathrm{H}_{2} \mathrm{O}$

None of the above primer sets cross-reacted with DNA from the host fish, the host snails or any other heterophyid species investigated. Faint bands were obtained, however, when using Haplorchis pumilio and $H$. taichui specific primer sets with the DNA of Dexiogonimus ciureanus. In order to avoid misidentification between these species, endonuclease restriction digest was applied. The digestion of the complete rDNA 18S PCR product, using Hin f1 restriction enzyme, yielded restriction fragments length polymorphisms among the 3 species (Fig. 3).

The phylogenetic analysis (Fig. 4) placed all species of the Heterophyidae (Order Opisthorchiida) in 1 clus-

ter. The heterophyid cluster segregated into 3 groups. The first group included Phagicola longa, Pygidiopsis genata and a Phagicola-like sp. from the USA, with the latter 2 being closely related. The second group including Haplorchis pumilio and $H$. taichui, both with 1 testis (i.e. Haplorchinae; sensu Witenberg 1929) and Dexiogonimus ciureanus (Heterophyinae; sensu Witenberg 1929), which have 2 testes. The final group included Centrocestus sp. from Israel and the cercariae of Centrocestus sp. infecting Melanoides tuberculata from the southern USA. There was, however, sufficient molecular evidence for the segregation of these 2 samples of Centrocestus into distinct species. The clustering of the remaining studied trematodes corresponded with their established taxonomic division into the orders Strigeidida, Echinostomida and Plagiorchiida (Fig. 4).

\section{DISCUSSION}

Species-specific PCR assays, based on rDNA 18S sequences as well as RFLP analysis, have proven useful in demonstrating genetic links between cercariae, metacercariae and adult worms of the Heterophyidae species. These tools may be used for early diagnosis as they were shown to be sensitive in the identification of

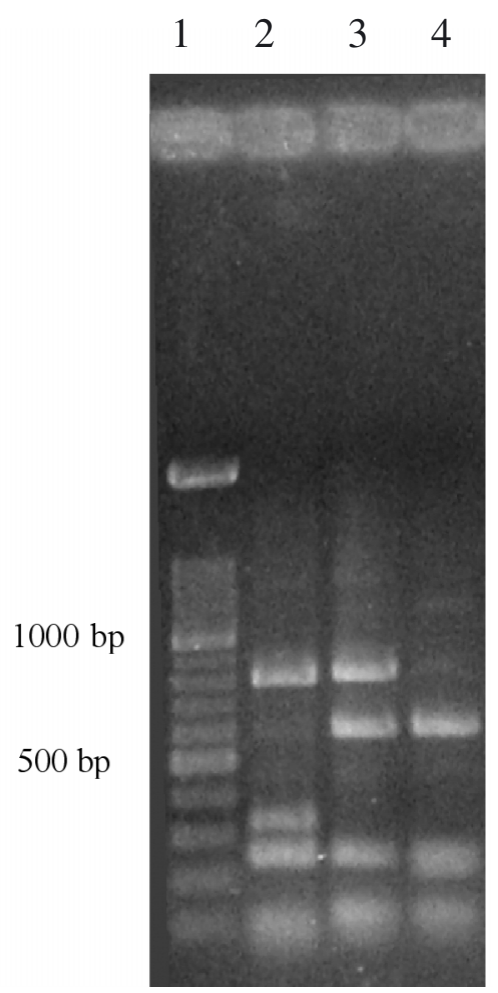

Fig. 3. Polymerase chain reaction amplified rDNA 18S digested with restriction enzyme Hin f1. Lanes 1 to 4: 1, $100 \mathrm{bp}$ DNA marker; 2, Haplorchis pumilio; 3, H. taichui; 4, Dexiogonimus ciureanus 


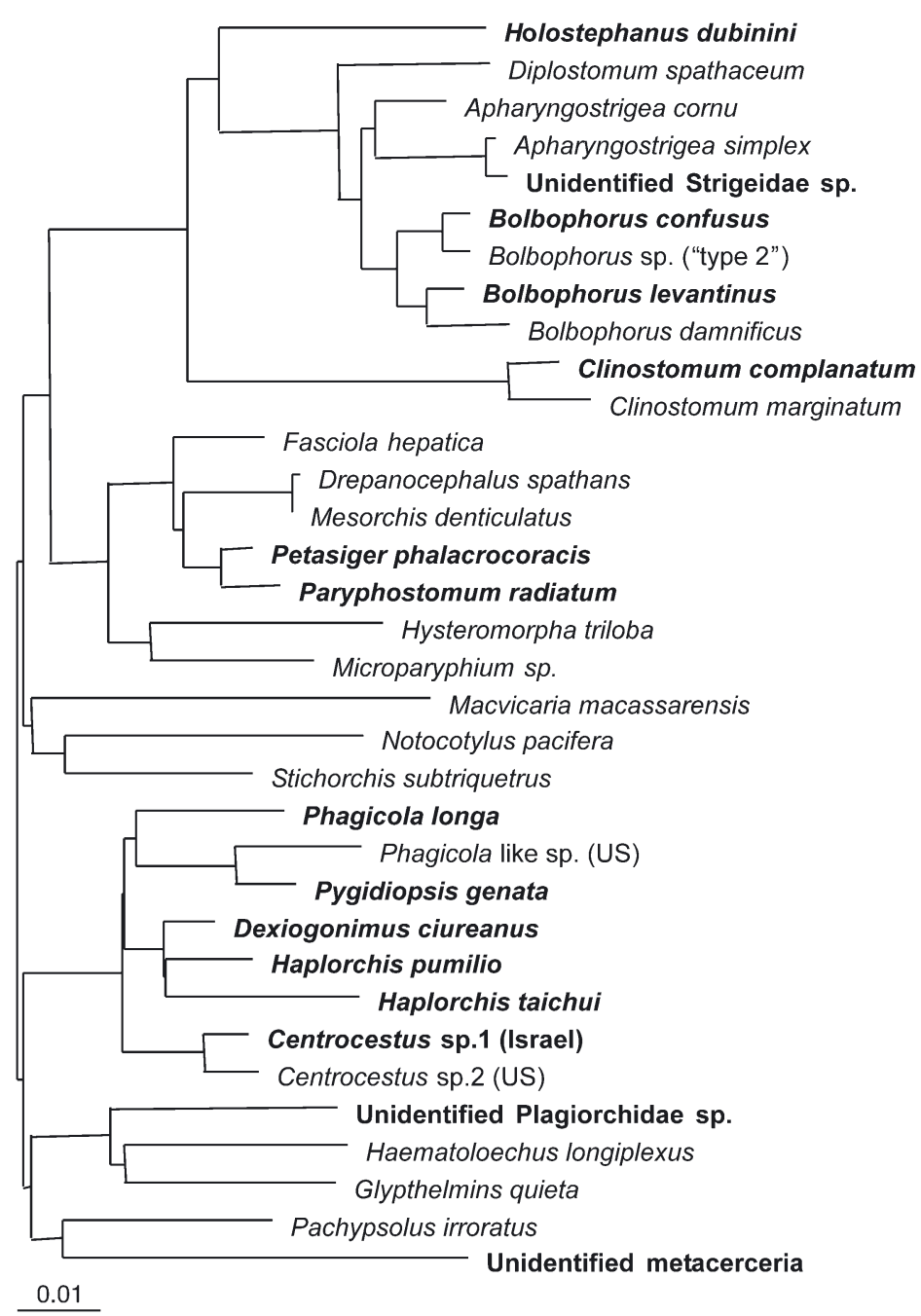

Strigeidida

Echinostomida

Opisthorchiida

(Heterophyidae)

Plagiorchiida

Fig. 4. Phylogenetic analysis of heterophyid species and their relations to other major groups of trematodes based on the alignment of the rDNA $18 \mathrm{~S}$ genes (species that were sequenced in the present study are in bold). Scale bar $=1 \%$ estimate difference in nucleotide sequence positions

early infections in snails even before cercariae were shed (Levy et al. 2002). Their application is significant for both fish and public health as well as for studying trematodes life history. Using this methodology we have elucidated the molluscan and piscine intermediate hosts of Pygidiopsis genata. Unveiling all the intermediate hosts of $P$. genata would make experimental infections applicable for the further studying of its life history. We anticipate that further use of Phagicola longa specific assay would enable, in the future, the elucidation of its first intermediate host. Haplorchis pumilio and $H$. taichui metacercarial and adult infections have been reported in a variety of fish mammals and birds in Israel (Witenberg 1929). However, although both species are transmitted by Melanoides tuberculata (Pearson 1964), in the present study we could only demonstrate the genetic links of all the life stages of $H$. pumilio. The reason may be that, as reported by Witenberg (1929), H. taichui is less common and therefore none of its cercariae and metacercaria were found.

Where experimental demonstration of the life history is unachievable, molecular methodologies have been employed to unveil the life histories of trematodes. The ITS rDNA region has been utilized for species-specific identifications (Cribb et al. 1998, Jousson et al. 1998, Anderson 1999). However, the validity of using the ITS region as a diagnostic tool has been questioned, since intra-specific variation has been found in the rDNA ITS loci of some echinostomatids and Paragonimus westermani (Sorensen et al. 1998, van Herwerden et al. 1999). Consequently, with our primer sets being designed for the variable regions in the $18 \mathrm{~S}$, we chose in our study to utilize the rDNA sequences of both the 
18S and ITS regions. The ITS regions may still be used for diagnostic confirmation and for the detection of intra- and inter-specific phylogenetic variation among isolates of poorly differentiated groups.

High-sequence similarity (96 to $98 \%$ identity) was shown within the $18 \mathrm{~S}$ rDNA sequence of the 6 representatives of the heterophyids. Because of this similarity we were obliged to design our specific primers to 1 location. Also, RFLP digestion was required in order to confirm differentiation between Dexiogonimus ciureanus and Haplorchis spp. This is the most remarkable example in our study of the high-genetic similarity of species of different genera, which were conventionally classified into different subfamilies, Heterophyinae and Haplorchinae, based on the presence of 2 testes and 1 testis, respectively (Witenberg 1929). Although a large amount of $18 \mathrm{~S}$ rDNA data is available for digenean, $18 \mathrm{~S}$ sequences for only 3 heterophyid were published (Olson et al. 2003) of which only Galactosomum lacteum, recovered from a cormorant, was an adult form. Even with the 6 new sequences, the molecular data available on rDNA of the Heterophyidae are still very limited. Therefore, the purpose of the presented tree was to put the newly sequenced species in their phylogenetic context, and it should be considered preliminary until, as was demonstrated for the Schistosomatidae, more data becomes available for comprehensive phylogeny analysis (Lockyer et al. 2003). In view of the discrepancies between the morphologybased classification and that established from genetic interrelations, future classifications should incorporate both morphological and genetic methodologies. Finally, it should be emphasized that additional species may not demonstrate variation at the same location of their $18 \mathrm{~S}$ sequence. Therefore, until more sequence data of this marginally investigated group becomes available, verification of the gene sequence is recommended when positive results of these assays are achieved.

Acknowledgements. This study was supported by the US-Israel Binational Science Foundation (BSF). Project No. 1999007.

\section{LITERATURE CITED}

Anderson GR (1999) Identification and maturation of the metacercaria of Indodidymozoon pearsoni. J Helminthol 73:21-26

Bartoli P, Jousson O, Russell-Pinto F (2000) The life cycle of Monorchis parvus (Digenea: Monorchiidae) demonstrated by developmental and molecular data. J Parasitol 86(3): 479-489

Cribb TH, Anderson GR, Adlard RD, Bray RA (1998) A DNAbased demonstration of a three host life-cycle for the Bivesiculidae (Platyhelminthes: Digenea). Int J Parasitol 28:1791-1795

Editorial responsibility: Wolfgang Körting,

Hannover, Germany
Deardorff TL, Overstreet RM (1990) Sea-food transmitted zoonoses in the United States: the fishes, the dishes, and the worms. In: Ward DR, Hackney C (eds) Microbiology of marine food products. Van Nostrand Reihold, New York, p 211-265

Grevelding CG, Kampkotter A, Kuntz W (1997) Schistosoma mansoni: sexing cercariae by PCR without DNA extraction. Exp Parasitol 85:99-100

Hillis DM, Dixon MT (1991) Ribosomal DNA: molecular evolution and phylogenetic inference. Q Rev Biol 66:411-453

Jousson O, Bartoli P, Zaninetti L, Pawlowski J (1998) Use of the ITS rDNA for elucidation of some life cycles of mesometridae (Trematoda, Digenea). Int J Parasitol 28:1403-1411

Ko RC (1995) Fish-borne parasitic zoonoses. In: Woo PTK (ed) Fish diseases and disorders: protozoan and metazoan infections, Vol 1. CAB International, Cambridge, p 631-671

Levy MG, Flowers JR, Poore MF, Khoo L and 5 others (2002) Morphologic, pathologic, and genetic investigations of Bolbophorus spp. (Diplostomatida, Trematoda) affecting cultured Ictalurus punctatus in the Mississippi Delta. J Aquat Anim Health 14:235-246

Littlewood DTJ, Olson PD (2001) Small subunit rDNA and the Platyhelminthes: signals, noise, conflicts and compromise. In: Littlewood DTJ, Bray RA (ed) Interrelationships of the Platyhelminthes. Taylor \& Francis, New York, p 262-278

Lockyer AE, Olson PD, Østergaard P, Rollinson D and 11 others (2003) The phylogeny of the Schistosomatidae based onthree genes with emphasis on the interrelationships of Schistosoma Weinland, 1858. Parasitology 126:203-224

Olson PD, Cribb TH, Tkach VV, Bray RA, Littlewood DTJ (2003) Phylogeny and classification of the Digenea (Platyhelminthes: Trematoda). Int J Parasitol 33:733-755

Paperna I (1995) Digenea (Phylum Platyhelminthes). In: Woo PTK (ed) Fish diseases and disorders: protozoan and Metazoan Infections, Vol 1. CAB International, Cambridge, p 329-389

Paperna I (1996) Parasites, infections and diseases of fishes in Africa-an update. Central Institute of Freshwater Aquaculture, Technical Paper no. 31, Food and Agriculture Organization, United Nations, Rome, p 122-142

Pearson JC (1964) A revision of the subfamily Haplorchinae Looss, 1899 (Trematoda: Heterophyidae) I. The Haplorchis group. Parasitology 54:601-676

Sambrook J, Fritsch EJ, Maniatis T (1989) Molecular cloning: a laboratory manual, 2nd edn. Cold Spring Harbor Laboratory Press, Cold Spring, New York, p 1.53-1.73

Sommervile C (1982) The pathology of Haplorchis pumilio (Looss 1986) infections in cultured tilapias. J Fish Dis 5: 243-250

Sorensen RE, Curtis J, Minchella DJ (1998) Intraspecific variation in the rDNA ITS loci of 37 collar-spined echinostomes from North America: implications for sequencebased diagnoses and phylogenetics. J Parasitol 84(5): 992-997

Strunk O, Ludwig W (1998) ARB: a software environment for sequence data. Department of Microbiology, Technische Universität München, Munich, www.mikro.biologie. tu-muenchen.de

van Herwerden L, Blair D, Agatsuma T (1999) Intra- and interindividual variation in ITS1 of Paragonimus westermani (Trematoda:Digenea) and related species: implications for phylogenetic studies. Mol Phylogenet Evol 12(1): $67-73$

Witenberg G (1929) Studies on the trematode family Heterophyidae. Ann Trop Med Parasitol 23(2):131-239

Submitted: July 10, 2003; Accepted: December 4, 2003

Proofs received from author(s): March 30, 2004 